\title{
College Entrance Credits at the University of Oklahoma
}

\section{F. A. BALYEAT}

$\mathrm{W}_{\mathrm{H}}$ what extent do the secondary schools meet this responsibility? On these matters there will remain disagreement and uncertaintly. Courses once considered essential for good work in college are now questioned or are repudiated as "musts" for the college entrant. Some subjects once required by most high schools are not now offered by many small schools and, where offered, are often electives.

In three previous articles, $\mathbf{1}$ the author showed trends in college entrance credits that were brought by freshmen entering the University of Oklahoma in the fall semester of 1907, 1917, 1927, 1937, and 1947. The studies included only graduates of public high schools of Oklahoma who presented no college credit, their transcripts used as the source of these data. All their credits were counted, even if exceeding the required sixteen units.

The present article treats in the same way the group entering in September 1957 with additional analysis of their credits, as shown in Tables II, IV, and V. A sixth column is added to Tables I, III, and VI, making comparison with the first five groups and showing some changes and trends in the past half-century. For all six classes, it is the percentage of the groups that is shown rather than the number of students. In the first four groups, all freshmen who met the above requirements were included, but in 1947 and 1957 only an adequate random sampling was studied. The 1957 group includes 400 men and 200 women, the approximate ratio of the two sexes among freshmen at this institution. The credits of the sexes are compared.

It should be noted that each group is limited to graduates of public high schools in Oklahoma. Therefore, the entire freshman class, including those from other states and some from non-public schools in Oklahoma, will differ somewhat from the groups sampled. Though the tables give a fairly accurate picture of the high-school offerings of the years immediately preceding any of the dates, it is important to remember that those entering this university took those courses considered helpful for work in college more than did those not preparing for college or who entered vocational schools.

\footnotetext{
${ }^{1 F}$. A. Balyeat, "Trends in College-Entrance Offerings," School Review, XXXVII (June 1029), 451-56; L (February 1942), 121-27; and LVI (June 1948), 350-56.

F. A. Balyeat is Professor Emeritus of Education, College of Education, University of Oklahoma, Norman, Oklahoma.
} 
The 600 entrants studied were selected in alphabetical order from among those qualifying under the limitations mentioned above until 400 men and 200 women were included. The author did this transcribing and carefully construed the subjects found on transcripts so as to place them properly under the classification used in the tables of the previous articles. Of the 77 counties of Oklahoma, all but a very few more distant and less populous ones were represented among the 600 cases. More than 75 per cent of them are from towns with high schools that provide ample subject matter offerings, as shown by the latest bulletin from the Oklahoma State Department of Public Instruction.

\section{Foreign Languages}

Table I compares the six groups with reference to the percentage bringing credit in each of the four languages taught in these schools. The decline in this field is well known. An interesting revelation is the leveling off, or rise, in the curve of foreign language credits. Latin still yields second place to Spanish, but with the margin of Spanish credits reduced. French regains some of its losses and German, so strong in 1917, maintains a low but rather steady curve. The percentage bringing

TABle I. PERCENTAGE OF ENTRANTS OF THE SIX CLASSES WITH CREDIT IN FOREIGN LANGUAGES, ENGLISH, AND SOCIAL STUDIES

\begin{tabular}{|c|c|c|c|c|c|c|c|}
\hline \multirow[b]{2}{*}{ Subjects } & & \multicolumn{6}{|c|}{ Percentage in each of six classes } \\
\hline & & 1907 & 1917 & 1927 & 1937 & 1947 & 1957 \\
\hline Latin: & $\begin{array}{l}4 \text { units } \\
3 \text { units } \\
2 \text { units } \\
1 \text { unit }\end{array}$ & $\begin{array}{r}37 \\
11 \\
42 \\
7\end{array}$ & $\begin{array}{r}10 \\
13 \\
53 \\
7\end{array}$ & $\begin{array}{r}4 \\
5 \\
39 \\
6\end{array}$ & $\begin{array}{r}2 \\
3 \\
30 \\
3\end{array}$ & $\begin{array}{r}1 \\
1 \\
18 \\
4\end{array}$ & $\begin{array}{r}1 \\
0 \\
23 \\
3\end{array}$ \\
\hline \multicolumn{2}{|l|}{ Total with Latin Credit: } & 97 & 83 & 54 & 38 & 24 & 27 \\
\hline Spanish: & $\begin{array}{l}2 \text { or more units } \\
1 \text { unit }\end{array}$ & $\begin{array}{l}0 \\
0\end{array}$ & $\begin{array}{l}3 \\
6\end{array}$ & $\begin{array}{r}34 \\
7\end{array}$ & $\begin{array}{r}24 \\
6\end{array}$ & $\begin{array}{r}30 \\
6\end{array}$ & $\begin{array}{r}23 \\
5\end{array}$ \\
\hline French: & 1 or more units & 0 & 2 & 7 & 14 & 3 & 6 \\
\hline Total with Modern Language Credit(1): & $\begin{array}{l}1 \text { or more units } \\
\operatorname{dit}\left({ }^{(}\right):\end{array}$ & $\begin{array}{l}4 \\
4\end{array}$ & $\begin{array}{l}36 \\
47\end{array}$ & $\begin{array}{r}1 \\
49\end{array}$ & $\begin{array}{r}1 \\
45\end{array}$ & $\begin{array}{r}1 \\
40\end{array}$ & $\begin{array}{r}1 \\
35\end{array}$ \\
\hline \multicolumn{2}{|c|}{ No Foreign Language Credit: } & 3 & 5 & 15 & 30 & 44 & 45 \\
\hline \multicolumn{2}{|l|}{ Miscellaneous English: } & $\begin{array}{r}0 \\
--\end{array}$ & 0 & 34 & 56 & 52 & $\begin{array}{r}30 \\
-\end{array}$ \\
\hline \multicolumn{2}{|l|}{ History: } & $\begin{array}{r}4 \\
20 \\
70 \\
6\end{array}$ & $\begin{array}{l}10 \\
33 \\
45 \\
12\end{array}$ & $\begin{array}{l}15 \\
41 \\
28 \\
16\end{array}$ & $\begin{array}{r}1 \\
19 \\
63 \\
17\end{array}$ & $\begin{array}{r}4 \\
29 \\
48 \\
19\end{array}$ & $\begin{array}{r}1 \\
18 \\
56 \\
25\end{array}$ \\
\hline Other Social Studies $\left({ }^{2}\right)$ : & $\begin{array}{l}2 \text { units } \\
1 \text { or } 11 / 2 \text { units } \\
1 / 2 \text { unit }\end{array}$ & $\begin{array}{r}0 \\
11 \\
69\end{array}$ & $\begin{array}{r}0 \\
17 \\
42\end{array}$ & $\begin{array}{r}1 \\
37 \\
30\end{array}$ & $\begin{array}{l}43 \\
25 \\
20\end{array}$ & $\begin{array}{r}2 \\
28 \\
13\end{array}$ & $\begin{array}{l}11 \\
37 \\
24\end{array}$ \\
\hline
\end{tabular}

$0.5 \%$ to $0.9 \%$ counted as 1.0 ; less than $0.5 \%$ counted as zero.

(1) Some bring credit in two or more foreign languages.

(2) Other social studies figures for 2 units in 1947 are wrong. 
four or more units still drops. Those with three or more units are usually from certain high schools in the larger towns where there are more language opportunities. The percentage with no foreign language credits is still high, but there is a little increase over 1947. They are not penalized in their college study because graduation requirements may be met through study of foreign language in college. Table II shows some interesting sex differences, the women inclined more to foreign language study. In interpreting conditions and trends shown, due consideration must be given to the fact that until recently many of the high-school pupils had very limited opportunities in this field.

\section{ENGLISH}

Two units of composition and two of literature, American and English, have been basic courses in Oklahoma high schools during the 50 years covered in this study. The first three groups averaged about 75 per cent with four units, when only three sufficed to meet state requirements. When four units were required, one of them could be from among those formerly listed as "miscellaneous" English. The 1937 group had 91 per cent with four units of the "basic" courses and the 1947 class indicated a slight increase. In 1957 we find at least 95 per cent with four units of composition and literature. In the last two articles, Table I has omitted this, because the four-unit offering is so prevalent.

"Miscellaneous" English was an unfortunate combination in earlier reports, concealing the specific courses studied. Table I shows that this group was too small to be recognized in 1907 and 1917, then reaching a peak in 1937, and declining to 30 per cent in 1957. These subjects are now more generally offered, but, with the total of subject choices now so large, as compared with earlier classes, the pupil's time for these subjects is limited. This factor applies to subjects in other fields.

Table II shows that in 1957 there were 32 per cent of the men with speech credit and 43 per cent of the women. This included work in drama and debate. More than three fourths of the total bringing speech credit had only one unit. Nine per cent of the 1957 group brought journalism credit, with women showing a stronger tendency to include this work. "Other English" includes business English, grammar, creative writing, and other courses infrequently listed. Only four per cent brought such credit.

\section{Social Studies}

All six groups show more time spent on high-school history than on the combined group of "other" social studies, which here includes government, economics, sociology, problems of democracy, industrial geography, psychology, and guidance, as well as a few others seldom listed. The total rose to an all-time high in 1937 when 88 per cent brought credit in this group, probably due to the new course in problems of democracy, then at its height. 
TABLE II. PERCENTAGE OF 1957 ENTRANTS WITH CREDIT IN FOREIGN LANGUAGES, ENGLISH, AND SOCIAL STUDIES

\begin{tabular}{|c|c|c|c|c|}
\hline \multirow[b]{2}{*}{ Subjects } & & \multicolumn{3}{|c|}{ Percentages } \\
\hline & & Men & Women & Total \\
\hline Latin: & $\begin{array}{l}3 \text { or } 4 \text { units } \\
2 \text { units } \\
1 \text { unit }\end{array}$ & $\begin{array}{r}1 \\
18 \\
3\end{array}$ & $\begin{array}{r}1 \\
32 \\
4\end{array}$ & $\begin{array}{r}1 \\
23 \\
3\end{array}$ \\
\hline Spanish: & $\begin{array}{l}2 \text { or more units } \\
1 \text { unit }\end{array}$ & $\begin{array}{r}20 \\
6\end{array}$ & $\begin{array}{r}28 \\
3\end{array}$ & $\begin{array}{r}23 \\
5\end{array}$ \\
\hline French: & 1 or more units & 4 & 8 & 6 \\
\hline German: & 1 or more units & 1 & 1 & 1 \\
\hline Foreign Language: & 3 or more units & 2 & 7 & 4 \\
\hline \multirow{2}{*}{\multicolumn{2}{|c|}{$\begin{array}{ll}\text { Speech }(1): & 1 \frac{1}{2} \text { or more units } \\
\text { Journalism: } & 1 / 2 \text { or } 1 \text { unit }\end{array}$}} & $\begin{array}{r}52 \\
-\frac{-}{5} \\
27\end{array}$ & $\begin{array}{c}30 \\
--- \\
14 \\
29\end{array}$ & $\begin{array}{r}45 \\
-\frac{-}{8} \\
27\end{array}$ \\
\hline & & 8 & 12 & 9 \\
\hline $\begin{array}{l}\text { "Other" Englis } \\
\text { History: }\end{array}$ & $\begin{array}{l}3 \text { or more units } \\
2 \text { units } \\
1 \text { unit }\end{array}$ & $\begin{array}{r}-3 \\
21 \\
54 \\
25\end{array}$ & $\begin{array}{r}-\frac{6}{13} \\
62 \\
25\end{array}$ & $\begin{array}{l}-\frac{4}{-}-- \\
19 \\
56 \\
25\end{array}$ \\
\hline Other Social Studies $\left({ }^{3}\right):$ & $\begin{array}{l}\text { More than } 2 \text { units } \\
1 \text { or } 11 / 2 \text { units } \\
1 / 2 \text { unit }\end{array}$ & $\begin{array}{l}12 \\
37 \\
24\end{array}$ & $\begin{array}{l}11 \\
38 \\
24\end{array}$ & $\begin{array}{l}11 \\
37 \\
24\end{array}$ \\
\hline $\begin{array}{l}0.5 \% \text { to } 0.9 \% \text { counted as } 1.0 \text {; } \\
\text { (1) Speech includes drama, deb } \\
\text { (2) "Other" English includes g } \\
\text { (3) Other social studies include } \\
\text { iidance, and a few others. }\end{array}$ & $\begin{array}{l}\text { an } 0.5 \% \text { counted as zet } \\
\text { ad a few others. } \\
\text { ar, creative writing, bus } \\
\text { ament, economics, sociol }\end{array}$ & $\begin{array}{l}\text { ss Eng } \\
\text { y, prob }\end{array}$ & $\begin{array}{l}\text { nd a few } \\
\text { f democr }\end{array}$ & sychology, \\
\hline
\end{tabular}

Oklahoma law requires for high-school graduation one unit of American history, including government. Formerly, when one unit each of ancient and modern history was generally offered, and frequently required, college entrants often had three or four units of history credit. Now, with these two usually combined in world history, and it often not a requirement for graduation, the percentage with three or four units has declined.

The 1957 group, as shown in Table II, had 56 per cent with two units of history credit and 19 per cent with three or more units. English history, as a separate course, has nearly disappeared, but Oklahoma history and Latin American history are provided by many of the schools. All except the required credit in the social studies have no doubt suffered in competition with other subjects now increasingly offered, and some of them so attractive to students, either for personal use or for possible vocational values. 


\section{Mathematics}

In the department of mathematics there has been striking change in recent years. Publicity about the deficiencies of recent freshman classes in colleges and the increasing warning about the danger of not being admitted to college or of not succeeding if admitted has had an obvious effect on the 1957 entrants. They, their parents, and their advisers have not ignored this interesting emphasis on the need for more mathematics for work in college and in more and more industries. Table III shows some of the recent trends, with recent upward swing in credits in the more advanced mathematics courses and the total credits in this department.

TABle III, PERCENTAGE OF ENTRANTS OF THE SIX CLASSES WITH CREDIT IN MATHEMATICS AND SCIENCE

\begin{tabular}{|c|c|c|c|c|c|c|c|}
\hline \multirow[b]{2}{*}{ Subjects } & & \multicolumn{6}{|c|}{ Percentage in each of six classes } \\
\hline & & 1907 & 1917 & 1927 & 1937 & 1947 & 1957 \\
\hline Algebra(1): & $\begin{array}{l}2 \text { units } \\
11 / 2 \text { units } \\
1 \text { unit }\end{array}$ & $\begin{array}{r}4 \\
84 \\
12\end{array}$ & $\begin{array}{r}1 \\
64 \\
35\end{array}$ & $\begin{array}{r}6 \\
38 \\
56\end{array}$ & $\begin{array}{l}10 \\
59 \\
21\end{array}$ & $\begin{array}{l}18 \\
36 \\
42\end{array}$ & $\begin{array}{l}59 \\
11 \\
28\end{array}$ \\
\hline Plane Geometry: & & 100 & 100 & 97 & 92 & 88 & 89 \\
\hline Solid Geometry: & & 77 & 39 & 16 & 15 & 19 & 30 \\
\hline Trigonometry: & & 4 & 11 & 10 & 19 & 27 & 32 \\
\hline Arithmetic: & & 0 & 22 & 28 & 29 & 24 & 3 \\
\hline General Science( $\left.{ }^{2}\right)$ : & & 0 & 8 & 50 & 60 & 57 & 57 \\
\hline Physics: & & 88 & 70 & 32 & 25 & 26 & 38 \\
\hline Chemistry: & & 15 & 20 & 23 & 28 & 31 & 45 \\
\hline Physical Geography and/or Geolog & & 80 & 65 & 32 & 29 & 22 & 10 \\
\hline Biology: & & 0 & 0 & 0 & 58 & 54 & 63 \\
\hline Botany: & & 61 & 32 & 32 & 3 & 1 & 0 \\
\hline Zoology: & & 23 & 19 & 28 & 3 & 0 & 0 \\
\hline Physiology: & & 46 & 9 & 19 & 7 & 5 & 3 \\
\hline All science: & $\begin{array}{l}3 \text { or more units } \\
2 \text { or } 21 / 2 \text { units }\end{array}$ & $\begin{array}{l}31 \\
50\end{array}$ & $\begin{array}{l}12 \\
33\end{array}$ & $\begin{array}{r}6 \\
22\end{array}$ & $\begin{array}{l}21 \\
41\end{array}$ & $\begin{array}{l}22 \\
40\end{array}$ & $\begin{array}{l}35 \\
33\end{array}$ \\
\hline
\end{tabular}

$0.5 \%$ to $0.9 \%$ counted as 1.0 ; less than $0.5 \%$ counted as zero.

(1) 2 units of algebra may include a semester of college algebra or may mean that vour semesters were spent to include intermediate algebra.

(2) Few, if any, Oklahoma high schools offered general science prior to 1915.

Further analysis of the credits of the 1957 group, as shown in Table IV, reveals some interesting facts. The men with more than one unit of algebra include 80 per cent of their group, compared with 53 per cent of the women. The total in plane geometry has changed little, but the 41 per cent of men with solid geometry and the 44 per cent with trigonometry does constitute a significant change. Counting the credits in general mathematics, business mathematics, and arithmetic, 25 per 
cent of the group brought four or more units and 63 per cent, three or more. The men included 77 per cent with three or more units. A study of both Tables III and IV reveals some of the most significant phases of the mathematics preparation of the 1957 entrants.

\section{SCIENCE}

In science subjects, especially physical science, is seen a significant change over the previous groups. Table III reveals an interesting shift in life science credits. Whereas the first three groups brought separate credit in zoology and botany, the last three have shown a gradual disappearance of these as separate courses, with continued stress on biology. While geology has increased, the offerings in physical geography have dropped off, making the combined figure decline steadily. General science, which entered Oklahoma high schools in 1915 with a textbook adoption that year, holds a steady percentage. The non-college bound high-school pupils earned less credit in physics and chemistry than did those in the group of 600 freshmen. Obviously, the growing information about the need of physical science in order to prepare for the attractive offers of industry is having its effect on both high-school and college enrollments.

TABLE IV. PERGENTAGE OF 1957 ENTRANTS WITH CREDIT IN MATHEMATICS AND SCIENCE

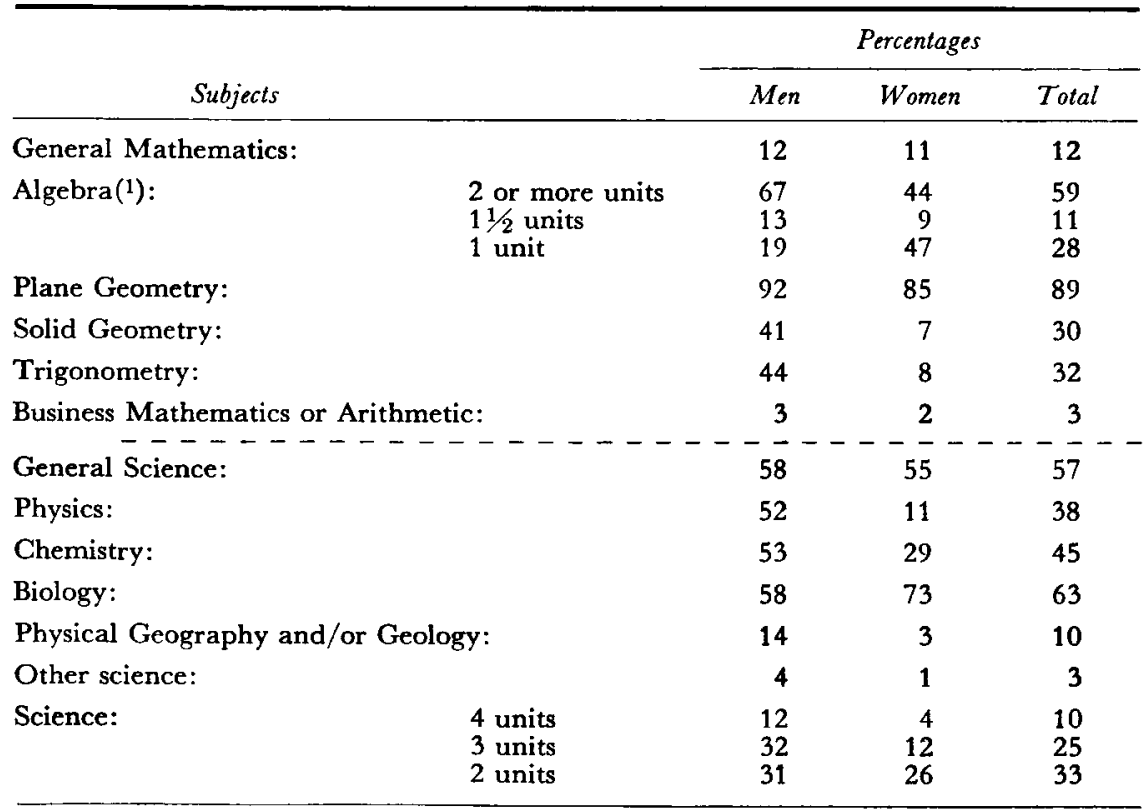

$0.5 \%$ to $0.9 \%$ counted as 1.0 ; less than 0.5 counted as zero.

(1) See note under Table II regarding 2 units of algebra. 
Table IV shows the preference of high-school boys for both physics and chemistry and of high-school girls for biology. With 35 per cent of the 1957 group bringing three or more units of science and with 68 per cent bringing two or more units, it seems that the recent efforts to interest more adolescents in science study is bearing fruit. Table IV shows some interesting sex differences, with indications that more and more of these students, especially the men, will be ready to prepare for the positions in modern industry.

Another condition is not obvious in these tables but is real and important. Boys who took agriculture in high school and girls who took home economics had a considerable amount of science study in those branches. Also, it is often of a more functional nature and, in many cases, really more educative. Also, some of the advanced study in the manual arts has to do with electricity and means that the boys who take it have had more total science growth than the table shows.

\section{Home ECONOMICS}

Listed as a vocational subject, home economics as usually taught in high school, is hardly that, except when we consider homemaking as an occupation. Much of the study is in the area of "personal use," an objective recently receiving more recognition in high-school teaching. Unfortunately, it is impossible to tell what percentage of the women who entered the previous classes brought credit in this department, due to the methods of entering credit in the office of admissions. Table $\mathrm{V}$ does show that 10 per cent of the 1957 women had one unit of credit, usually meaning non-vocational. Another seven per cent had two units and five per cent had three units, or more, making a total of 22 per cent of the women with credit in home economics.

\section{Manual Arts}

Manual arts is continued in this article, though the term most commonly used now is industrial arts. The former was used in the three previous studies. The 19 per cent of men with only one unit had more of the "personal use" training. Some of the 11 per cent with two units and the 11 per cent with three or more would include some who had the basis of vocational training. The total of 41 per cent of men with manual arts credit makes a significant number. Table VI shows that nine per cent of these men had agriculture credit, most of them of the vocational type. This included enough farm shop study to add materially to their growth in manual arts.

The percentage in trade and industry, diversified occupations, and distributive education, as shown in Table $\mathrm{V}$, is very small. Really, though, the number of schools giving this work is relatively small and a good many of them have added this training only recently. Also, many who take this work in high school would not be among those entering a state university. 
TABEE V. PERGENTAGE OF 1957 ENTRANTS WITH CREDIT IN VOCATIONAL SUBJECTS, FINE ARTS, PHYSICAL EDUCATION, AND DRIVER EDUCATION

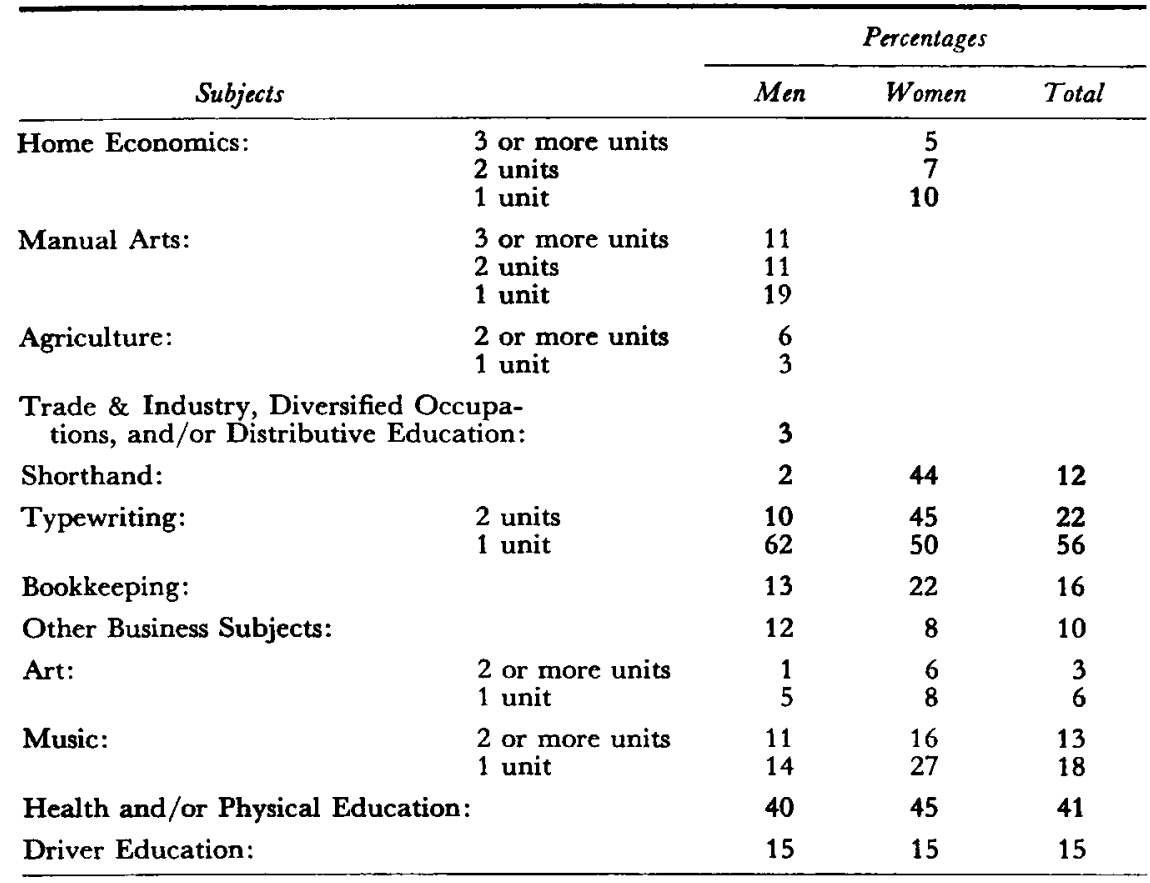

$0.5 \%$ to $0.9 \%$ counted as 1.0 ; less than $0.5 \%$ counted as zero.

Some of the women with home economics credit and the men with manual arts credit will probably project this pattern of study so that they may well prepare to teach their departments in high school. Others will in this study find themselves vocationally and further prepare in college to fit themselves for positions in industry.

\section{Business Education}

This is another department that gives much instruction of a personal use nature. Typewriting proficiency is being advertised, maybe too much, as a means of improving college grades. Whatever the effective influence, it is interesting to note that stenography has held its percentage in spite of keen competition with other high-school courses added in recent years. Again, it is unfortunate that in the earlier studies it was impossible to determine what was shorthand and what was typewriting in the university records. The fact that 72 per cent of the men and 95 per cent of the women in the sampling of 600 in the 1957 class had typewriting is worthy of notice. Nearly half of these women brought two units of typewriting. Shorthand credit is shown mainly in the group of women and is probably vocational for them. Much of the bookkeep. 
ing training in high school is non-vocational, especially for the men. The total of the "other" business courses is not large, though many non-college bound pupils have taken these courses. Many of the women and some of the men in the 1957 group, as did those in previous groups, will use their knowledge and skills to help earn their expense in college. A good many, especially the women, will prepare to teach business subjects in high school.

\section{FINE ARTS}

Music is the only fine art to be shown in Table VI. Added in recent years in most schools, it has made a steady growth, except in the 1947 group. It should be noticed here, and considered in connection with some other departments, that in the 1947 class there was a higher percentage of men, due to the large number having been recently separated from military service. Table $V$ shows that 25 per cent of the men and 43 per cent of the women brought music credit in 1957, most of them in half-unit increments and totaling only one unit. This includes participation in music groups in high school, if accompanied by credit in music theory.

Table VI. PERCENTAGE OF ENTRANTS OF THE SIX CLASSES WITH CREDIT IN VOCATIONAL SUBJEGTS, FINE ARTS, AND PHYSICAL EDUCATION

\begin{tabular}{lrrrrrrr}
\hline & \multicolumn{5}{c}{ Percentage in each of six classes } \\
\cline { 2 - 7 } \multicolumn{1}{c}{ Subjects } & 1907 & 1917 & 1927 & 1937 & 1947 & 1957 \\
\hline Home Economics or Manual Arts(1): & 0 & 47 & 50 & 43 & 59 & 41 \\
Agriculture, General or Vocational: & 0 & 27 & 26 & 11 & 19 & 9 \\
Commercial Law: & 0 & 10 & 23 & 27 & 14 & 3 \\
Stenography(2): & 0 & 5 & 37 & 65 & 68 & 69 \\
Bookkeeping: & 0 & 13 & 19 & 20 & 15 & 16 \\
Miscellaneous English: & 0 & 0 & 34 & 56 & 52 & 43 \\
Music, Theory or Applied, or both: & 0 & 2 & 21 & 33 & 18 & 29 \\
\hline
\end{tabular}

$0.5 \%$ to $0.9 \%$ counted as 1.0 ; less than $0.5 \%$ counted as zero.

(1) The studies prior to 1957 did not study the sexes separately, nor did the records in earlier years distinguish between home economics and manual arts credits in University files.

(2) In earlier years shorthand and typewriting were entered in University records as stenography.

Art still has a low representation among those who enter the University of Oklahoma, with women showing twice the tendency than men to earn such credit. Of the 14 per cent of women with art credit, six per cent had two or more units, indicating a probable development of interest and skill that may lead to further study in college and may probably be applied to teaching or to use in industry. Some of the men with one unit of art are those with manual arts credit, probably combining the two fields in the development of their interests and proficiencies. 


\section{Health and Physical Education}

It is very difficult to separate these two closely related areas. Some of the credits listed were first aid or other subject matter courses. Other entrants had courses that stressed physical fitness as part of the content and as a major objective. While it is impossible to compare this group with previous ones, the author has evidence that far fewer of the men are given credit for team participation than was true several years ago. Most of the credit was from high schools with subject matter offerings in physical education, with teachers certified in that field. Also, many of the larger schools give, and sometimes require, class work in physical education without counting the credits as part of the sixteen units required for graduation.

\section{Driver Education}

The latest group, still a small one, is in the safety education course that stresses driver education, with one-half unit of credit. It is interesting to note that 15 per cent represents the proportion of both men and women who bring this credit.

\section{Conclusion}

Tables I, III, and VI present some evidence that freshmen entering the University of Oklahoma in 1957 should be better prepared to succeed in college than have those of previous years. Tables II, IV, and V add to this impression. Of course, the amount and kind of entrance credit are by no means the only or the main consideration. Amount of residual and functional knowledge of the courses taken is very important. We have nothing on which to compare the six groups in this respect, but there is little ground to hope that the 1957 group is of higher scholarship than were those who preceded them. It is probably the right and the duty of receiving colleges to test the applicants and screen out, as early as possible, those who show too little evidence of having the kind and the quality of preparation needed for the lines of work indicated.

The public high schools are faced with difficult problems, some nonexistent when the earlier classes in this study were preparing for college. In recent years a large percentage of high-school pupils have no intention of attending college. These have a right to courses within their capacities and suited to their interests and needs. With the budgets and the faculties available, especially in smaller schools, it is very hard to serve well both those preparing for college and those who are not. Neither should suffer because of this complex problem. With the recent closing of many smaller high schools, enabling their pupils to attend schools with better offerings and teaching; with continued improvement of teachers; with better guidance of high-school pupils and better cooperation of their parents; and with more effective cooperation between high schools and colleges-with all these changes it has become possible to send the 1957 group better prepared for college success. There is still much room for improvement, but, also, some ground to expect continued improvement in the total situation. 